\title{
Performance of Microfinance Institutions in Asia: DEA based efficiency analysis
}

\author{
Farhana Ferdousi \\ Dept. of Political Economics \\ Wuhan University \\ Wuhan, P.R. China \\ dfferdousi@gmail.com
}

\author{
Lecturer \\ South East University \\ Bangladesh.
}

\begin{abstract}
The paper attempted to investigate the comparative performance of microfinance institutions (MFIs) in three Asian countries namely Bangladesh, India and China. Based on data envelopment analysis, best practice MFIs have been identified and their efficiency determinants also have been investigated by using tobit regression analysis. Findings revealed that MFIs in China and India performs more efficiently than that of Bangladesh under constant return to scale technology but under variable return to scale technology MFIs in Bangladesh perform more efficiently than others. Moreover, regression analysis confirms that the performance of MFIs in terms of total assets and financial performance in terms of profitability is critical for sustainable and efficient development of MFIs.
\end{abstract}

Keywords- microfinance institutions; data envelopment analysis; constant return to scale; variable return to scale

\section{INTRODUCTION}

Microcredit is the practice of providing small loans to poor people who are not conventionally being served by the commercial bank, was first pioneered in Bangladesh in the 70s and $80 \mathrm{~s}$ by Nobel laureate Mohammad Yunus and the organization he founded, Grameen Bank. Following the success of Grameen Bank, this financial innovation has not only been used in Bangladesh alone, but also has been replicating by the most other countries in the world with some modification based on contextual differences. Although the term micro credit evolved in 1970s, are now shifting toward microfinance which demand more attention toward commercialization of microfinance institutions by adopting more innovative and demand driven financial products while maintaining institutional sustainability of MFIs. The current state of the art of performance assessment in micro-finance involves two main schools of thought: the intended beneficiary school which focuses on impact on users, and the intermediary school, which focuses on the ability of the service provider to sustain its operations into the future $[1,2]$ by building efficient market, reducing transaction cost and ensuring better management of risk. In the initial stage of microfinance market development, huge fund had been attracted from donors, but as increasing numbers of MFIs are entering into the market, share of donor funds are getting scarce. Therefore, efficient use of internal resources by the MFIs is getting more importance. The present study attempted to analyze the efficiency of Micro finance institutions from three countries in Asia. Two countries from south Asia: One is the micro finance pioneering country
Bangladesh, and another is India which is the largest emerging market for micro finance industry. Over the past decade, the Microfinance sector has been growing in India at a fairly steady pace. Though no microfinance institution (MFI) in India has yet reached anywhere near the scale of the well-known Bangladeshi MFIs, the sector in India is characterized by a wide diversity of methodologies and legal forms [3]. Among the East Asian part, China has large portfolio of microfinance and has potential market for microfinance expansion. Data have been collected from the website of mixmarket database [4] which includes 42 MFIs from China, 89 MFIs from India and 34 MFIs from Bangladesh. Based on Data Envelopment Analysis (DEA), efficiency analysis had been performed to find out the best practice MFIs among the three countries and tobit regression analysis have been adopted to find out the determinants of efficiency for future development.

\section{LITERATURE REVIEW}

There exists significant literature that measures efficiency of MFIs. But the methods to measure efficiency are not unique in nature. Reference [5] uses borrower per staff and saver per staff for measuring efficiency. Higher levels of these measures suggest that MFIs' high productivity of the staff assists in accomplishing their two operational goals of financial sustainability and borrower outreach. High levels of these measures may result in high level of efficiencies in MFI. Other MFI studies have used typical variables used in studies of banking efficiencies. For instance, reference [6] uses administrative expense ratio, number of loans, and loans to total staff members to examine MFI efficiencies. Moreover, he also considers loan size, lending methodology, sources of funds, and salary structure as drivers of efficiencies.

None of these two studies use any parametric or nonparametric approach to evaluate the efficiency of MFIs. In addition to the conventional financial ratios, the assessment can also be done using the efficiency analysis of MFIs [7]. There exists significant literature that assess the efficiency of traditional financial institutions by employing non parametric techniques i.e. Data Envelopment Analysis (DEA) [8] which has been widely employed in recent times. Though normally associated with the efficiency analysis of the Traditional Banking Sector, some researchers have successfully replicated it for the efficiency Analysis of MFIs. 
By applying the non parametric method DEA, Fadzlan Sufian [9] tried to analyze the efficiency of NFBIs of Malaysia, for the period 2000-2004. During this period the study revealed that only $28.75 \%$ of 80 observations are efficient, and that the size and the part of the market have a negative effect on the efficiency. Finally, he concluded that the NFBIs which are more efficient tend to be more profitable. Using Data Envelopment Analysis (DEA), reference [10, \& 11] analyze MFIs in Vietnam and Peru, respectively. Furthermore, reference [12 \& 7] use DEA to compare MFI performance across regions.

The other key MFI paper is that of Hassan and Tufte [13] using a parametric approach (stochastic frontier analysis or SFA) found that Grameen Bank's branches staffed by the female employees operated more efficiently than their counterparts staffed by the male employees. Further, Desrochers and Lamberte [14] have also used parametric approaches to study the efficiency of cooperative rural banks in the Philippines. They found that cooperative rural bank with good governance were more efficient than their counters faced by bad governance. Reference [15] reported that productivity of resources, governance, and business environment were the contributing factors for the cost-efficiency of the Peruvian municipal banks.

Employing the Stochastic Frontier Analysis, reference [16] analyzed Indian MFIs. Reference [17] analyzed a sample of MFIs across the world using SFA and a semi parametric smooth coefficient cost function, respectively. Reference [18] estimated a parametric cost function of MFIs in Eastern Europe and Central Asia and account for unobserved heterogeneity using a mixture model.

\section{MEASURING INPUT AND OUTPUT VARIABLES}

The description of the variables used as input and output for efficiency measure are given in the table 1 . Definitions of the variables follow the definition provided by the mix market information exchange database.

\section{EFFICIENCY OF MFIS IN CHINA, INDIA, AND BANGLADESH}

Various efficiency of MFIs in China, India and Bangladesh are measured using data envelopment analysis (DEA). The overall efficiency is measured under the assumption of constant return to scale where as pure technical efficiency and the scale efficiency are measured by assuming variable return to scale.
TABLE I. INPUT AND OUTPUT VARIABLES

\begin{tabular}{|l|l|l|l|}
\hline Variable & \multicolumn{1}{|c|}{$\begin{array}{c}\text { Variable } \\
\text { name }\end{array}$} & \multicolumn{1}{|c|}{ Definition } & Unit \\
\hline Input & $\begin{array}{l}\text { Operating } \\
\text { expense }^{1}\end{array}$ & $\begin{array}{l}\text { Operating expense as a percentage } \\
\text { of gross loan portfolio }\end{array}$ & \$mber of \\
staff $^{2}$ & $\begin{array}{l}\text { Total number of staff members. } \\
\text { Pross Loan }^{\text {Portfolio }}\end{array}$ & $\begin{array}{l}\text { All outstanding principals due for } \\
\text { all outstanding client loans. This } \\
\text { includes current, delinquent, and } \\
\text { renegotiated loans, but not loans } \\
\text { that have been written off. }\end{array}$ & No. \\
\hline Output & $\begin{array}{l}\text { Number of } \\
\text { active } \\
\text { borrowers }\end{array}$ & $\begin{array}{l}\text { The numbers of individuals or } \\
\text { entities who currently have an } \\
\text { outstanding loan balance with the } \\
\text { MFI or are primarily responsible } \\
\text { for repaying any portion of the } \\
\text { Loan Portfolio, Gross. }\end{array}$ & \\
\hline
\end{tabular}

Average output oriented TE (Technical efficiency), PTE (Pure Technical Efficiency) and SE (Scale Efficiency) are $40.3 \%, 48.6 \% \& 82.4 \%$ for China, $32.1 \%, 39.2 \%$ \& $76.9 \%$ for India and $56.4 \%, 63.1 \%$ \& $88.7 \%$ for Bangladesh respectively. It implies that most of the technical inefficiency of MFIs in all the three countries is due to the pure technical inefficiency rather than the scale inefficiency in all cases. Therefore, it can be concluded that MFIs in China, India and Bangladesh can increase their output by 51.4, 50.8 and 36.9 percent respectively with the existing level of input by efficient utilization of resources.

There are $21.42 \%$ MFIs in China, $7.87 \%$ in India and 91.18\% of MFIs in Bangladesh are operating at the stage of increasing returns of scale. The result suggests that among the three countries, MFIs in Bangladesh are enjoying comparatively greater economies of scale.

Efficiency analysis found 12 best practice MFIs from the three countries when constant return to scale is considered. Among them China has 6 MFIs (CFPA, Harbin Bank, JinjiLake, Maanshan, NHMCL), India has 5 MFIs (Pustikar, Sanghamithra, SHARE, Spandan and WSE) and only one Grameen Bank from Bangladesh. When variable return to scale is considered, 14 MFIs from the above three countries shows either pure technical efficiency or scale efficiency. YESC from China, ABASSS, Equitas, SEIL, \& SKS from India and CSS, JCF, GJUK, \& Muslim Aid from Bangladesh shows pure technical efficiency under VRS, beside these, Gansu Wushan URDA from China, Swamashree Micro Credit Services from India and ASA, BRAC \& Buro Bangladesh from Bangladesh show scale efficiency under the same consideration.

\section{ANALYSIS OF EFFICIENCY DETERMINANT}

This section investigates the possible determinants of efficiency of MFIs in three Asian countries. We propose different variables that can explain the efficiency of MFIs.

\footnotetext{
${ }^{1}$ Reference $[19,20]$

${ }^{2}$ Reference [21, 22, 23]

${ }^{3}$ Reference [19, 21,24]

${ }^{4}$ Reference [22]
} 
These variables can be divided into different groups based on location, basic characteristics, financial management and performance. We used both correlation and the regression analysis in this section.

First variable that we considered is the location of the MFI. While dealing with three countries in Asia, we used three location dummies as CHN, IND and BAN for China, India and Bangladesh respectively.

The second category relates to the characteristics of MFIs in terms of size. To capture the effect of the size of MFI we used total value of assets (TA). We hypothesize larger firms may perform better than those of smaller size.

The variable that represents the financial management of MFIs is Debt-Equity ratio. It is expected that higher debt-equity ratio reduces firms efficiency. The last set of variables represents the performance of the MFIs which is represented by the rate of return on assets (ROA), which is expected to have positive association with firm efficiency.

\section{A. Correlation Analysis}

We have calculated the correlation coefficients between different efficiency measures and the variables defined above. The correlation coefficients are presented in Table 2 . The results show that the value of total assets, debt/equity ratio and the returns on assets are positively correlated with all efficiency measures. In case of location, the Bangladesh and China MFIs have positive correlation with all three measures of efficiency, whereas Indian MFIs has negative correlation with all efficiency measures.

TABLE II. CORRELATION COEFFICIENT BETWEEN THE DIFFERENT EFFICIENCY MEASURES AND THE VARIABLE DEFINED

\begin{tabular}{|c|c|c|c|}
\hline Variables & TE & PTE & SE \\
\hline Asset & $\mathbf{0 . 2 5 2 8}$ & $\mathbf{0 . 2 2 1 2}$ & $\mathbf{0 . 1 5 3 2}$ \\
\hline $\begin{array}{c}\text { Debt/Equity } \\
\text { ratio }\end{array}$ & $\mathbf{0 . 0 5 1 9}$ & $\mathbf{0 . 0 3 5 9}$ & $\mathbf{0 . 1 0 4 0}$ \\
\hline $\begin{array}{c}\text { Return on } \\
\text { asset }\end{array}$ & $\mathbf{0 . 1 8 9 6}$ & $\mathbf{0 . 1 9 4 0}$ & $\mathbf{0 . 2 5 0 8}$ \\
\hline China & $\mathbf{0 . 0 9 9 5}$ & $\mathbf{0 . 0 9 5 9}$ & $\mathbf{0 . 0 8 6 1}$ \\
\hline India & $\mathbf{- 0 . 3 1 5 1}$ & $\mathbf{- 0 . 3 3 4 0}$ & $\mathbf{- 0 . 2 8 7 7}$ \\
\hline Bangladesh & $\mathbf{0 . 2 7 9 5}$ & $\mathbf{0 . 3 0 5 6}$ & $\mathbf{0 . 2 6 0 0}$ \\
\hline
\end{tabular}

\section{B. Regression Analysis}

The results of regression analysis are presented in Table 3 . The value of adjusted R2 shows that $65 \%$ of variation in the technical efficiency is explained by the variables included in the model. In case of pure technical efficiency this variation is $58 \%$, while for scale efficiency model the included variable explains only $20 \%$ of the variations. The parameter estimate of the size variable represented by the total value of assets is significant having positive sign. It implies that the size of the MFI is important in determining both TE and PTE levels.
TABLE III. DETERMINANTS OF EFFICIENCY OF MFIS IN ASIA

\begin{tabular}{|c|c|c|c|c|c|c|}
\hline \multirow{2}{*}{$\begin{array}{c}\mathrm{V} \\
\text { ariabl } \\
\text { es }\end{array}$} & \multicolumn{2}{|c|}{$\begin{array}{c}\text { Dependent } \\
\text { variable: CRSTE }\end{array}$} & \multicolumn{2}{|c|}{$\begin{array}{c}\text { Dependent } \\
\text { variable: VRSTE }\end{array}$} & \multicolumn{2}{|c|}{$\begin{array}{c}\text { Dependent } \\
\text { variable: SCALE }\end{array}$} \\
\hline & $\begin{array}{l}\text { Coef } \\
\text { ficient }\end{array}$ & $\begin{array}{r}t- \\
\text { statistic }\end{array}$ & $\begin{array}{l}\text { Coef } \\
\text { ficient }\end{array}$ & $\begin{array}{r}t- \\
\text { statistic }\end{array}$ & $\begin{array}{c}\text { Coef } \\
\text { ficient }\end{array}$ & $\begin{array}{r}t- \\
\text { statistic }\end{array}$ \\
\hline Asset & $e-11^{4.28}$ & $9^{* *} 3.1$ & $\mathrm{e}-11^{3.81}$ & $8^{* * *} 2.7$ & $\mathrm{e}-11^{1.25}$ & 1.75 \\
\hline DER & $4082^{.000}$ & $\begin{array}{ll}5_{5} & 0.3\end{array}$ & $1949^{.000}$ & $6 \quad 0.1$ & 7776.000 & 1.25 \\
\hline ROA & $7104^{1.11}$ & $3^{*} 2.3$ & $9237^{1.13}$ & $3^{*} 2.3$ & $2914^{.785}$ & ** 3.10 \\
\hline $\mathrm{CHN}$ & $\begin{array}{l}- \\
.104278 \\
4\end{array}$ & $1.60^{-}$ & $\begin{array}{l}- \\
.120846 \\
1\end{array}$ & $1.82^{-}$ & $\begin{array}{l}{ }^{-} \\
.042749 \\
3\end{array}$ & $1.24^{-}$ \\
\hline IND & $\begin{array}{l}- \\
.210051 \\
3\end{array}$ & $4.00^{-\frac{-}{* * *}}$ & $\begin{array}{l}- \\
.233912 \\
1\end{array}$ & $4.37^{-}$ & $\begin{array}{l}- \\
.097191 \\
4\end{array}$ & $3.49^{-}$ \\
\hline BNG & $8714^{.512}$ & $94^{* * * *} 10$. & $1622^{.600}$ & $56^{* * * *}$ & $0617^{.859}$ & $4^{* * * *} 34.5$ \\
\hline $\begin{array}{l}\text { Log } \\
\text { likelih } \\
\text { ood } \\
\quad P \\
\quad \text { Peudo } \\
\text { R2 }\end{array}$ & \multicolumn{2}{|c|}{$\begin{array}{l}-8.8441052 \\
0.6501\end{array}$} & \multicolumn{2}{|c|}{$\begin{array}{l}-11.831174 \\
0.5842\end{array}$} & \multicolumn{2}{|c|}{$\begin{array}{l}85.76264 \\
-0.1985\end{array}$} \\
\hline
\end{tabular}

With respect to location while Bangladeshi MFIs shows significant positive association with all efficiency measure, Indian MFIs shows significantly negative relationship and Chinese MFIs shows negative but non-significant relationship with all efficiency measures.

\section{CONCLUSION}

The objective of this study has been to benchmark the best practice MFIs thereby to estimate the efficiency and its determinants. For the efficiency analysis the Data Envelopment Analysis Approach was followed. The result of DEA analysis suggests that among the three countries, MFIs in Bangladesh are enjoying comparatively greater economies of scale. Chinese and Indian MFIs are more likely to be efficient under constant return to scale consideration while Bangladeshi MFIs are more likely to be efficient under variable return to scale consideration. On an average source of inefficiency was identified as pure technical in nature than to the scale inefficiency for all the countries. Therefore, improved management skills are required for all the MFIs in the sample countries in order to ensure the efficient utilization of available input to enhance increased outreach and performance of MFIs. However, the results from the regression analysis lead to conclude that size of MFI is important in the determination of efficiency of MFIs. The second important conclusion is that the MFIs return on assets (ROA) should be positive, else it becomes less efficient.

\section{REFERENCES}

[1] Johnson, S. Programme impact assessment in micro finance: the need for analysis of real markets1. IDS Bulletin, vol. 29(4), pp. 21-30, 1998. 
[2] Hulme, D., Mosley, P., Wilson, F. A., \& Coker, A. Finance against poverty, Vol. 1 and 2. Project Appraisal, 12(2), pp.131-132, 1997.

[3] Varman, P. M. "Benchmarking microfinance institutions in India and determinants of their technical efficiency", Indian Journal of Economics and Business, vol. 7(2), pp. 255-265, 2008.

[4] www.mixmarket.org

[5] Baumann, T. "Pro poor microcredit in South Africa: Cost efficiency and productivity of South African pro-poor microfinance institutions", Journal of Microfinance, vol. 7(1), pp. 95-118, 2005.

[6] [Farrington, T. Efficiency in microfinance institutes. Microbanking Bulletin, pp. 20-23, 2000.

[7] Nawaz, A. Efficiency and Productivity of Microfinance: Incorporating the Role of Subsidies: ULB--Universite Libre de Bruxelleso, 2010.

[8] Charnes, A., Cooper, WW. and Rhodes, E. "Measuring the efficiency of decision making units", European journal of operational research, vol. 2(6), pp. 429-444, 1978.

[9] Sufian, F. "The efficiency of non-bank financial institutions: empirical evidence from Malaysia", International Journal of Finance and Economics, vol.6, 2006.

[10] Nghiem, H., Coelli, T., \& Rao, P. "The efficiency of microfinance in Vietnam: Evidence from NGO schemes in the north and the central regions" International Journal of Environmental, Cultural, Economic and Social Sustainability, vol. 25, pp.71-78, 2006.

[11] Flückiger, Y., \& Vassiliev, A. "Efficiency in microfinance institutions: an application of data envelopment analysis to MFIs in peru". Microfinance and public policy: outreach, performance, and efficiency, 2007.

[12] Haq, M., M. Skully and P. Shams. "Efficiency of microfinance institutions: A Data Envelopment analysis", SSRN working paper 1405709,2009 .

http://papers.ssrn.com/sol3/papers.cfm?abstract_id=1405709, (accessed 15 October 2011).

[13] Kabir Hassan, M., \& Tufte, D. R. The x-efficiency of a group-based lending institution: The case of the Grameen Bank. World Development, vol. 29(6), pp. 1071-1082, 2001.
[14] Desrochers, M., \& Lamberte, M. Efficiency and expense preference behavior in Philippines, cooperative rural banks. Centre interuniversitairesur les risque, les politiques economiques et al'emploi (CIRPÉE.) Cahier de recherche/Working paper 03-21, 2003.

[15] Leon, J. V. Cost frontier analysis of efficiency: an application to the Peruvian Municipal Banks. Ohio State University, 2001.

[16] Masood, T., \& Ahmad, M. (2010). Technical Efficiency of Microfinance Institutions in India-A Stochastic Frontier Approach. Technical Efficiency of Microfinance Institutions in India-A Stochastic Frontier Approach , 2008.

[17] Hartarska, V., \& Mersland, R. (2009). "Which governance mechanisms promote efficiency in reaching poor clients? Evidence from rated microfinance institutions", European Financial Management, vol. 18(2), pp.218-239, 2009.

[18] Caudill, S. B., Gropper, D. M., \& Hartarska, V. "Which microfinance institutions are becoming more cost effective with time? Evidence from a mixture model", Journal of Money, Credit and Banking, vol. 41(4), pp. 651-672, 2009.

[19] Athanassopoulos, AD. "Service quality and operating efficiency synergies for management control in the provision of financial services: evidence from Greek bank branches", European journal of operational research, vol.98(2), pp. 300-313, 1997.

[20] Gutierrez-Nieto, B., Serrano-Cinca, C. and Molinero, C. M. "Social efficiency in microfinance institutions", Journal of the Operational Research Society, vol. 60(1), pp.104-119, 2007.

[21] Berger, AN and Humphrey, DB. "Efficiency of financial institutions: International survey and directions for future research", European journal of operational research, vol. 98(2), pp.175-212, 1997.

[22] Bolli, T., \& Thi, A. V. On the estimation stability of efficiency and economies of scale in microfinance institutions. KOF Swiss Economic Institute Working Paper (296), 2012.

[23] Pastor, JM. "Efficiency and risk management in Spanish banking: a method to decompose risk", Applied Financial Economics, vol.9(4), pp.371-384, 1999.

[24] Sherman, HD and Gold, F. "Bank branch operating efficiency: evaluation with data envelopment analysis", Journal of Banking \& Finance, vol. 9(2), pp.297-315, 1985. 